\title{
Prevalence of Dysmicoccus brevipes (Cockerell, 1893) (Hemiptera: Pseudococcidae) in MD2 pineapple crop areas in Colombia ${ }^{1}$
}

\author{
Isabel Moreno ${ }^{2}$, Rubilma Tarazona-Velásquez ${ }^{2}$, \\ Yenifer Campos-Patiño ${ }^{2}$, Kevin Alejandro Rodríguez-Arévalo ${ }^{2}$, Takumasa Kondo ${ }^{2}$
}

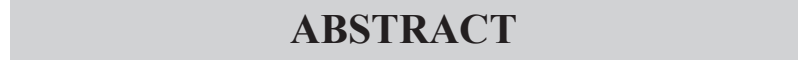

Pineapple mealybug wilt has been reported as one of the most important diseases affecting pineapple crops worldwide. This study aimed to determine the prevalence of mealybugs associated with two agroclimatic zones of pineapple production in the department of Valle del Cauca, Colombia. The survey was conducted in the upper (Dagua, Restrepo, La Cumbre and Vijes) and lower (Buga and Palmira) land zones. A total of 75 MD2 pineapple plots in different development growth stages were evaluated. The mealybugs were recorded mainly in the upper land zone, with a prevalence of $32 \%$. Concerning the plots growth stages, the highest prevalence was observed in second-cycle plots $(13.3 \%)$, followed by third-cycle ones, including abandoned plots (9.3\%), and first-cycle plots $(6.7 \%)$, which were associated with the use of pesticides. Dysmicoccus brevipes was the only mealybug species (Pseudococcidae) found on pineapples in the study area.

KEYWORDS: Ananas comosus, Dysmicoccus brevipes, mealybug, insect pest.

\section{INTRODUCTION}

Pineapple or ananás [Ananas comosus (L.) Merr. (Bromeliaceae)] is a perennial plant grown in 86 countries throughout the world (FAO 2019). Some regional cultivars, such as Manzana, Perolera, Mayanesa and India, are currently cultivated in different regions in Colombia, for export and internal consumption (Neira García et al. 2016, Rios 2020). However, these cultivars are currently being displaced by the MD2 hybrid, also known as Golden sweet, due to the preference of national and international markets (Rios 2020), and that has imposed challenges

\begin{abstract}
RESUMO
Prevalência de Dysmicoccus brevipes (Cockerell, 1893) (Hemiptera: Pseudococcidae) em áreas de cultivo de abacaxi MD2 na Colômbia

A murcha do abacaxizeiro tem sido relatada como uma das doenças mais importantes para a cultura do abacaxi em todo o mundo. Objetivou-se determinar a prevalência de cochonilhas associadas a duas zonas agroclimáticas de produção de abacaxi no departamento de Valle del Cauca, Colômbia. A pesquisa foi realizada nas zonas alta (Dagua, Restrepo, La Cumbre e Vijes) e baixa (Buga e Palmira). Um total de 75 parcelas de abacaxi MD2 em diferentes etapas de desenvolvimento foi avaliado. As cochonilhas foram registradas principalmente na zona alta, com prevalência de $32 \%$. Em relação às etapas de crescimento das parcelas, a maior prevalência foi observada nas parcelas do segundo ciclo (13,3\%), seguidas pelas do terceiro ciclo, incluindo as parcelas abandonadas $(9,3 \%)$, e as do primeiro ciclo (6,7 \%), que esteve associado ao uso de agrotóxicos. Dysmicoccus brevipes foi a única espécie de cochonilha farinhenta (Pseudococcidae) encontrada em abacaxis na área de estudo.
\end{abstract}

PALAVRAS-CHAVE: Ananas comosus, Dysmicoccus brevipes, cochonilha, inseto-praga.

to the local growers, such as reaching an adequate agronomic management and yield.

The pineapple production has increased its participation in the Colombian economy with 32,735 ha of cultivated area, production of $1,058,109 \mathrm{t}$ and average yield of $31.05 \mathrm{tha}^{-1}$ (Asohofrucol 2019). The Valle del Cauca region has 2,343 ha dedicated to pineapple, with a production of 15,162 $\mathrm{t}$ (Agronet 2018), of which $58 \%$ are destined for export (Agronegocios 2019). In this region, the pineapple production is established in two agroecological zones: the upper land zone, characterized by small planting areas with traditional management; and the

\footnotetext{
${ }^{1}$ Received: Feb. 23, 2021. Accepted: July 23, 2021. Published: Aug. 30, 2021. DOI: 10.1590/1983-40632021v5167838.

${ }^{2}$ Corporación Colombiana de Investigación Agropecuaria - Agrosavia, Centro de Investigación Palmira, Palmira, Valle del Cauca, Colombia.E-mail/ORCID: mimoreno@agrosavia.co/0000-0001-9257-6645; rtarazona@agrosavia.co/0000-0002-4837-8024; ycampos@agrosavia.co/0000-0002-5209-8340; karodriguez@agrosavia.co/0000-0002-1058-8464;
} 
lower land zone, which is part of the valley, with a greater area of cultivation and implementation of technical management, which, in most of the cases, corresponds to the production of pineapple for export.

In the Valle del Cauca region, a preliminary survey (Mesa et al. 2014) showed that the predominant pests causing major damage to pineapple crops are the megarus scrub-hairstreak Strymon megarus (Godart) (Lepidoptera: Lycaenidae), the snout beetle Metamasius dimiatipennis Jekel (Coleoptera: Dryophthoridae), the symphilid Scutigerella inmaculata (Newport) (Symphyla: Scutigerellidae) and the mealybug Dysmicoccus brevipes (Cockerell) (Hemiptera: Pseudococcidae). The survey was conducted in different municipalities of this region, in 180 orchards cultivated with the MD2 hybrid and the local cultivar Manzana. The study also revealed that $90 \%$ of the growers used pesticides to control insect pests following calendar applications.

Mealybugs (Hemiptera: Coccomorpha: Pseudococcidae) are small, soft-bodied, sap-sucking insects. The female has 4 instars. The first instar, in which the nymphs are commonly known as crawlers, is the dispersal stage, and the adult stage (fourth instar) is reached after three further molts (Williams \& Watson 1988). They are distributed around the world, especially in tropical areas (Williams \& Granara de Willink 1992). Some species are vectors of viruses that cause diseases in crops of various agroecosystems (Roivainen 1976, Raine et al. 1986, Lockhart et al. 1992, Sether et al. 1998, Kubiriba et al. 2001, Tsai et al. 2010).

The pineapple mealybug wilt is considered one of the main diseases affecting pineapple crops around the world, being characterized by severe tip dieback, downward curving of leaf margins, reddening and wilting of leaves, and may cause the total collapse of the plant (Sether \& Hu 2002). It has been associated to a complex of Ampelovirus species referred to as Pineapple Mealybug Wilt-associated Viruses (PMWaVs), which are transmitted by two species of mealybugs: the pink pineapple mealybug $D$. brevipes and the gray pineapple mealybug $D$. neobrevipes (Beardsley) (Carter \& Collins 1933, Sether et al. 1998). D. brevipes was first reported on Ananas comosus in Colombia in 1946 (Figueroa-Potes 1946), but D. neobrevipes has not been reported for the crop yet.

This study aimed to identify the presence and prevalence of mealybug species found in pineapple plantations of the Valle del Cauca department,
Colombia, as a first step to understand their role as insect vectors of PMWaVs and the dynamics of the disease transmission in the region.

\section{MATERIAL AND METHODS}

Municipalities of the Valle del Cauca (Colombia) with major MD2 pineapple cultivated areas (Dagua, Restrepo, La Cumbre and Vijes) were selected based on data from Agronet (2018), corresponding to small and medium size orchards of the upper land zones. Palmira and Buga, which are located at the lower land zones, were also surveyed, in order to include contrasting data from plantations with technical management.

Once the pineapple orchards were selected, an exploratory survey was conducted to confirm the presence of mealybugs, from February to August 2019. The survey consisted of random exploration of the cultivated plots and their surroundings, in order to identify possible factors associated with Pineapple Mealybug Wilt (PMW). For that, plants were randomly selected to check for the presence of mealybugs on leaves, stems, roots, suckers and fruits (Figure 1). The orchards in which the presence of mealybugs was confirmed during the exploratory survey were selected for sample collection. Scale insect specimens were collected under a collecting permit by the Colombian National Authority Environmental Permits (resolution $n^{\circ} .1466$ December 3, 2014).

Mealybugs and other scale insects were slidemounted (Sirisena et al. 2013) and identified to species level. The specimens were studied under a Nikon Eclipse E200 phase contrast compound microscope. The mealybugs (Pseudococcidae family) were identified to species level using the keys by Williams \& Granara de Willink (1992); the soft scales (Coccidae family) were identified to the genus level using the keys by Hodgson (1994) and to species using the keys by Kondo (2010); and the armored scales (Diaspididae family) were identified to species level using the keys by Miller \& Davidson (2005). Voucher specimens were deposited at the Colección Taxonómica Nacional de Insectos "Luis María Murillo", Corporación Colombiana de Investigación Agropecuaria - Agrosavia, Mosquera, Cundinamarca, Colombia.

Exploratory surveys were conducted in a total of 47 orchards and $75 \mathrm{MD} 2$ pineapple cultivated plots, in six municipalities of the Valle del Cauca department 

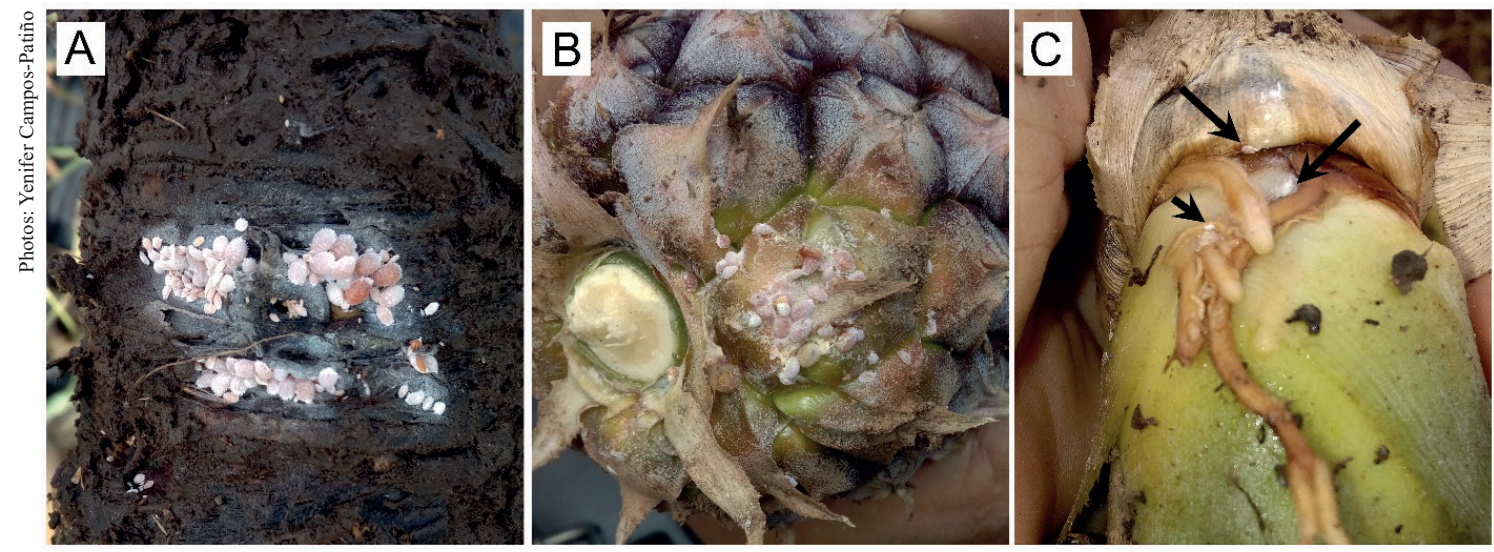

Figure 1. Mealybugs and some plant parts where they can be found: A) root crown; B) fruit; C) basal sucker (see arrows).

of Colombia, located in two agroecological zones: Dagua, La Cumbre, Restrepo and Vijes, in the upper land zone; and Palmira and Buga, in the lower land zone (Table 1). The location and distribution of the plots according to the mealybug infestation levels are described in Figure 2.
For each surveyed MD2 pineapple plot, the presence or absence of mealybugs was recorded. The pineapple orchards ranged from very large (about 10 ha) to small (1 ha) orchards. Some larger orchards are often subdivided into plots. Generally, a single orchard may be composed of plots cultivated with

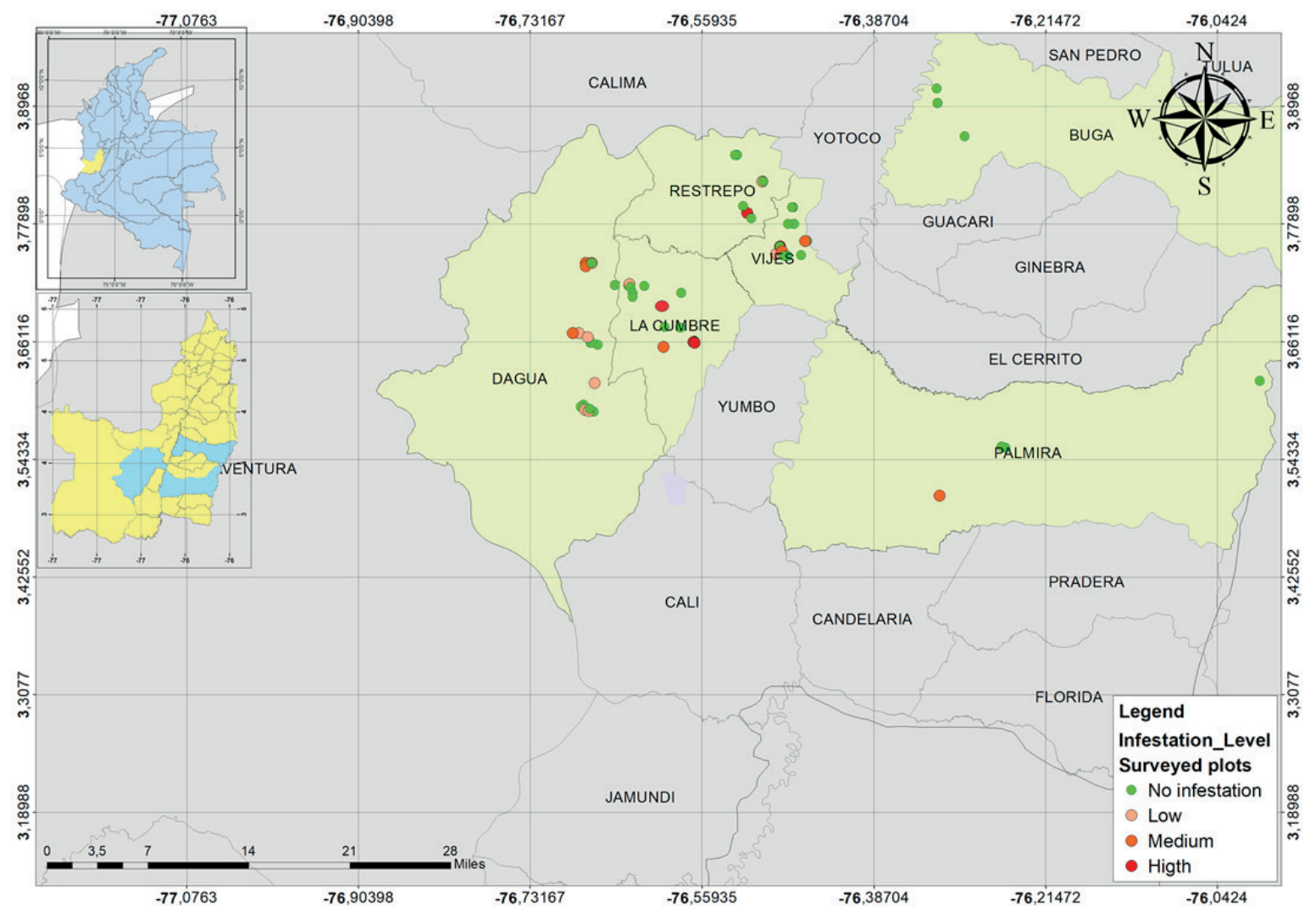

Figure 2. Geographical distribution of the plots where the exploratory surveys were conducted (green and red dots). Green dots show the plots without mealybug infestation and red dots the plots with presence of mealybugs. The infestation level is indicated by the color intensity. 
Table 1. Location, number of orchards and plots visited during the exploratory survey at the Valle del Cauca department, Colombia.

\begin{tabular}{|c|c|c|c|}
\hline Municipality & Locality & $\begin{array}{c}\text { Number of } \\
\text { orchards }\end{array}$ & $\begin{array}{l}\text { Number of } \\
\text { plots }\end{array}$ \\
\hline Buga & Quebrada seca & 2 & 4 \\
\hline \multirow{7}{*}{ Dagua } & Villa Hermosa & 2 & 5 \\
\hline & San Joaquín & 3 & 6 \\
\hline & Jiguales & 4 & 6 \\
\hline & Atuncela & 3 & 4 \\
\hline & Bolivia & 1 & 1 \\
\hline & El Llanito & 1 & 1 \\
\hline & El Diamante & 1 & 3 \\
\hline \multirow{6}{*}{ La Cumbre } & La María & 7 & 7 \\
\hline & Pavas & 2 & 2 \\
\hline & Las Colonias & 1 & 5 \\
\hline & La Guaira & 1 & 1 \\
\hline & La Rumorosa & 1 & 3 \\
\hline & Murales & 1 & 1 \\
\hline \multirow{2}{*}{ Palmira } & Barrancas & 1 & 2 \\
\hline & Agrosavia & 1 & 1 \\
\hline \multirow{4}{*}{ Restrepo } & Agua mona & 1 & 2 \\
\hline & Diamante & 1 & 2 \\
\hline & Palma & 2 & 2 \\
\hline & Monte Redondo & 1 & 1 \\
\hline \multirow{4}{*}{ Vijes } & La Rivera & 1 & 3 \\
\hline & Fresneda Alta & 1 & 2 \\
\hline & Cienaguitas & 3 & 5 \\
\hline & Cachimbal & 5 & 7 \\
\hline Total & & 47 & 75 \\
\hline
\end{tabular}

pineapple at different stages of development and different production cycles, to allow a continuous harvest throughout most of the year. A production cycle is the period from planting or new flowering induction to harvest. In general, after the first production cycle, most farmers keep the plantation for a second cycle or ratoon cycle. In the Valle del Cauca region, after the second production cycle, some farmers leave the plantation for a third cycle, to obtain an extra income, in which agronomic management is absent. Third-cycle plots where the farmers expressed no intention of conducting any agronomic management were considered as abandoned. Thus, the pineapple plots and/or small orchards were classified into three categories, namely: 1) first production cycle; 2) second production cycle; and $3)$ third production cycle, including abandoned plots.

The mealybug prevalence $(\mathrm{P})$ was calculated with the formula: $\mathrm{P}=\mathrm{c} / \mathrm{d} * 100$, where $\mathrm{c}$ is the total number of plots with mealybugs and $\mathrm{d}$ the total number of studied plots.
The infestation level was calculated according to the average number of mealybugs found in each plant plot $^{-1}:$ i) absent (no infestation); ii) low: 1-30 mealybugs plant ${ }^{-1}$; iii) medium: 31-100 mealybugs plant $^{-1}$; iv) high: 101 or more mealybugs plant ${ }^{-1}$. These categories were determined arbitrarily based on the mealybug populations observed in a preliminary field survey.

The data gathered in each plot were analyzed for presence and prevalence of mealybugs according to two variables: i) level of mealybug infestation; ii) production cycle. In addition, a test of independence based on sample size, type of variables and data distribution was chosen (Webster 2000). A Fisher's exact test was conducted between the infestation level and production cycle data to accept or reject the null hypothesis of independence between these two variables in the MD2 studied pineapple plots. An analysis was conducted with the R software 3.4.3 (R Core Team 2017).

Non-parametric tests were conducted to analyze a possible correlation between the presence of mealybugs and the agronomic, environmental and social qualitative variables (Wackerly et al. 2010). A Kruskal-Wallis test was used to prove the independence between the qualitative variables and a Dunn test applied to determine the significance level of the correlation between variables using the R software 3.4.3 (R Core Team 2017). The gathered information was subjected to a data cleansing process, in which all selected variables were analyzed and only those that showed an association with the presence of mealybugs were selected.

\section{RESULTS AND DISCUSSION}

From the exploratory surveys, a total of 24 MD2 pineapple cultivated plots were confirmed to have mealybug infestation (5 first-cycle, 10 secondcycle and 14 third-cycle plots, including abandoned plots), which represent $32 \%$ of mealybug prevalence in the studied area. The lowest mealybug prevalence was observed in first-cycle plots with $6.7 \%$, explained by the intense application of pesticides generally used for pest control. Most of the plots with mealybug infestation were in the upper land zone. Only one plot was located at the lower land zone, and it corresponded to a second-cycle production plot. This difference in mealybug infestation between zones could be associated with the differences in crop 
management strategies between the zones, i.e., pest control being more intensive in lower land zones.

The number and production cycle of the plots were surveyed randomly, with the production cycle corresponding to that at the time of the survey. The number of plots visited per production cycle was as it follows: 36 first-cycle plots, 27 second-cycle plots and 12 third-cycle plots, including abandoned plots. The first and second production cycles are the traditional cycles of pineapple cultivation. This explains the lower number of plots explored in the third cycle. Regarding the infestation level, most of the plots had a low level of infestation, followed by the medium and high infestation levels, in this respective order. A high level of infestation was found only in plots of the second and third cycles (including abandoned plots). The Fisher's exact test rejected the null hypothesis of independence between the variables ( $p$-value $=0.001022 ; \alpha=0.05$ ), suggesting a possible level of dependence between them. The distribution data of the number of plots with presence of mealybugs according to the level of infestation per production cycle is described in Table 2 .

The distribution of the prevalence of mealybugs according to the level of infestation and production cycle is described in Figure 3. The highest prevalence of mealybugs was found in the low infestation level in the third cycle, including abandoned plots (6.7 \%), and in the medium infestation level in the secondcycle plots $(5.3 \%)$. The low prevalence of mealybugs in all plots of the first production cycle $(6.7 \%)$, if compared with the plots in other cycles, may be explained by the intense chemical control conducted by farmers during this cycle. A high percentage of plots in the first cycle also recorded no mealybugs (41\%), corresponding to all the 31 surveyed plots (Table 2).

A data cleansing process of the information gathered from the survey allowed to select 26 variables, which were categorized as agronomic, environmental and social. The Kruskal-Wallis test rejected the null hypothesis of independence between the analyzed qualitative variables $\left[\mathrm{X}^{2}(26,0.05)=\right.$ 38.885], with a confidence level of $95 \%$. The Dunn analysis determined the level of significance between variables, and the null hypothesis was rejected for the 10 variables with $p$-value $<0.05$, which had significant correlations (Table 3 ).

Among the agronomic variables, the production cycle showed a positive relationship, whereas the seed treatment had a negative relationship. Mealybug infestations were found in advanced production cycles regardless of the size of the orchard in which the use of pesticides was low or absent. Additionally,

Table 2. Distribution of the number of surveyed plots according to the infestation level and production cycle.

\begin{tabular}{lcccc}
\hline Production cycle / Infestation level & First & Second & Third/abandoned & Marginal frequency \\
\hline No infestation & 31 & 17 & 3 & 51 \\
Low & 2 & 3 & 5 & 10 \\
Medium & 3 & 4 & 2 & 9 \\
High & 0 & 3 & 2 & 5 \\
Marginal frequency & 36 & 27 & 12 & 75 \\
\hline
\end{tabular}

Table 3. List of qualitative variables with significant correlation* with the presence of mealybugs.

\begin{tabular}{lllc}
\hline \multicolumn{1}{c}{ Category } & \multicolumn{1}{c}{ Variable } & P-value & Relationship \\
\hline \multirow{2}{*}{ Agronomic } & Production cycle & $0.0014^{*}$ & Positive \\
& Basal sucker/seed treatment & $0.0188^{*}$ & Negative \\
\hline \multirow{4}{*}{ Environmental } & Altitude & $0.0000^{*}$ & Positive \\
& Flat land & $0.0089^{*}$ & Positive \\
& Irregular land & $0.0013^{*}$ & Negative \\
\hline \multirow{3}{*}{ Social } & Flooding & $0.0085^{*}$ & Negative \\
& Associativity & $0.0085^{*}$ & Negative \\
& Technical assistance & $0.0188^{*}$ & Negative \\
& Land ownership & $0.0005^{*}$ & Negative \\
& Bookkeeping & $0.0188^{*}$ & Negative \\
\hline
\end{tabular}




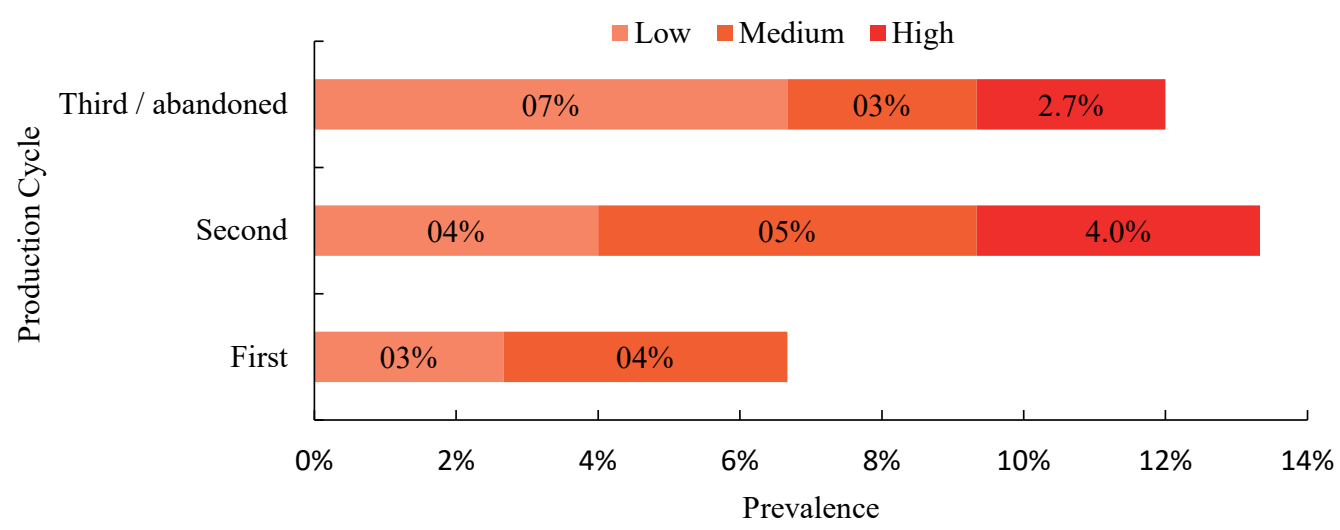

Figure 3. Distribution of mealybug prevalence by level of infestation (low, medium and high) in each production cycle.

the use of basal suckers for vegetative propagation is a method commonly employed by the pineapple farmers in this region, and this practice helps the dispersal of the mealybugs. A negative relationship with the level of mealybug infestation was observed when the seed was chemically treated before planting.

Regarding the environmental variables, a positive relationship was found with the altitude and flat land variables. This can be explained because the plots with mealybug infestations were located in the upper land zone, in plots characterized by dry flat land. All social variables showed negative relationships. Farmers who were landowners, members of pineapple growing associations, as well as farmers who receive technical assistance and carried out bookkeeping, had less mealybug infestation in their plots. Most of the qualitative variables selected based on the information gathered from the farmers agreed with our results and our observations during the exploration survey.

According to our exploratory survey, farmers usually control mealybugs in the region using chemical pesticides, especially in plots in the first production cycle, which made up the bulk of visited plots. Farmers generally apply insecticides according to calendar applications. Pesticide doses are higher during the first production cycle and are reduced in the second and third production cycles, and prior to harvest. The most common chemical products used in the studied area are 1B class organo-phosphates (chlorpyrifos and diazinon) and $3 \mathrm{~A}$ class pyrethroids (cypermethrin and deltamethrin), that cause negative environmental impacts and affect fruit quality and food safety. At the same time, the production system is at risk by the appearance of mealybug resistance to pesticides, which is explained by the overuse of the chemical compounds (Venkatesan et al. 2016). Documentation of insecticide resistance in mealybugs across the globe is limited and insecticide resistance has not been reported for Dysmicoccus spp. on pineapple. However, resistance to different pesticides have been reported for other mealybug species in other crops, e.g., Pseudococcus viburni (Signoret) [= Pseudococcus affinis (Maskell)] (Charles et al. 1993); Pseudococcus maritimus (Ehrh.) (Flaherty et al. 1982); Planococcus citri (Risso) (Venkatesan et al. 2016); and Phenacoccus solenopsis Tinsley (Saddiq et al. 2014). The current scenario in the MD2 pineapple growing areas of the Valle del Cauca demands the development of integrated pest management alternatives, which can be used by the farmers to control mealybugs in a way that they preserve the production system and the environment.

Pineapple mealybugs cause direct damage to the host plant, reduce the market value because their presence results in the rejection of fruits for export, and are vectors of virus species associated with pineapple mealybug wilt (PMW). Hitherto, in MD2 pineapple plots, no symptoms associated with the disease have been observed, but a previous and preliminary study reported PMWaV2 in two regions of Colombia (Rodelo 2007). It is thought that the MD2 hybrid was introduced to Colombia from plant propagation material (suckers) via Ecuador (Rodelo 2007). Pineapple farmers obtain the plant material either from established local nurseries or by planting suckers from their own orchards. The plant material produced by the farmers has no sanitary certification, and thus plants are not tested for virus infection. Besides vector transmission, the propagation of 
infested plant material is a common pathway of virus transmission in vegetatively propagated crops (Hillocks \& Thresh 2000, Thresh 2006, Dieryck et al. 2009). Clean material from certified nurseries should be used to avoid the propagation of plant pathogens.

All mealybug samples were identified as D. brevipes (Cockerell) (Pseudococcidae), in agreement with the study by Mesa et al. (2014), who also reported this mealybug species on pineapple in the department of Valle del Cauca. The study was aimed at MD2 pineapples, but we also collected D. brevipes from the regional cultivar Manzana. Other scale insects identified during the present study are Diaspis bromeliae (Kerner, 1778) (Hemiptera: Diaspididae) and Cryptostigma rhizophilum Kondo, 2010 (Hemiptera: Coccidae). Diaspis bromeliae was found affecting the leaves of many plants in one lot in an orchard of the lower land zone, and C. rhizophilum was found on the roots of one plant in an orchard of the upper land zone.

\section{CONCLUSION}

Dysmicoccus brevipes is prevalent in MD2 pineapple orchards cultivated in the Valle del Cauca region, Colombia.

\section{ACKNOWLEDGMENTS}

The authors thank the Ministerio de Agricultura y Desarrollo Rural de Colombia, for funding this research, which is part of the project entitled "Technological options for the development and sustainable management of pineapple cultivation Ananas comosus (L.) Merr. (Bromeliaceae) in the main producing areas of Colombia", and Dr. Penny Gullan (Australian National University, Camberra), for reviewing the article and providing useful comments.

\section{REFERENCES}

AGRONEGOCIOS. La producción de piña en Colombia llegaría a 1,18 millones de toneladas al finalizar el año. 2019. Available at: https://www.agronegocios.co/ agricultura/la-produccion-de-pina-en-colombia-llegariaa-118-millones-de-toneladas-al-finalizar-el-ano-2895397. Access on: 15 Aug. 2020.

AGRONET. Estadísticas agropecuarias. 2018. Available at: https://www.agronet.gov.co/estadistica/Paginas/home. aspx?cod=1. Access on: 18 Aug. 2020.
ASOHOFRUCOL. Balance del sector hortifrutícola. 2019. Available at: http://www.asohofrucol.com.co/ interna.php? $\mathrm{cat}=3 \& \mathrm{scat}=45 \& \mathrm{act}=1$. Access on: $20 \mathrm{Aug}$. 2020.

CARTER, W.; COLLINS, J. L. The pineapple mealybug, Pseudococcus brevipes (Ck1.) and wilt of pineapples. Phytopathology, v. 23, n. 3, p. 207-242, 1933.

CHARLES, J. G.; WALKER, J. T. S.; WHITE, V. Resistance to chlorpyriphos in the mealybug Pseudococcus affinis and P. longispinus in Hawke's Bay and Waikato pipfruit orchards. In: NEW ZEALAND PLANT PROTECTION CONFERENCE, 46., 1993, Christchurch. Proceedings... Rotorua: New Zealand Plant Protection Society Inc., 1993. p. 120-125.

DIERYCK, B.; OTTO, G.; DOUCET, D.; LEGRÈVE, A.; DELFOSSE, P.; BRAGARD, C. Seed, soil and vegetative transmission contribute to the spread of pecluviruses in western Africa and the Indian sub-continent. Virus Research, v. 141, n. 2, p. 184-189, 2009.

FIGUEROA-POTES, A. Catalogación inicial de las cochinillas del Valle del Cauca [Homoptera: Coccoidea]. Revista Facultad Nacional De Agronomía Medellín, v. 6, n. 23, p. 196-220, 1946.

FLAHERTY, D. L.; PEACOCK, W.; BETTIGA, L.; LEAVITT, G. M. Chemicals losing effect against grape mealybug. California Agriculture, v. 36, n. 1, p. 15-16, 1982.

FOOD AND AGRICULTURE ORGANIZATION OF THE UNITED NATIONS (FAO). Faostat database. 2019. Available at: http://www.fao.org/faostat/en/\#data/ QC. Access on: 9 June 2021.

HILLOCKS, R. J.; THRESH, J. M. Cassava mosaic and cassava brown streak virus diseases in Africa: a comparative guide to symptoms and etiologies. Roots, v. 7, n. 1, p. 1-8, 2000.

HODGSON, C. J. The scale insect family Coccidae: an identification manual to genera. Wallingford: $\mathrm{CAB}$ International, 1994.

KONDO, T. Taxonomic revision of the myrmecophilous, meliponiphilous and rhizophilous soft scale genus Cryptostigma Ferris (Hemiptera: Coccoidea: Coccidae). Zootaxa, v. 2709, n. 1, p. 1-72, 2010.

KUBIRIBA, J.; LEGG, J. P.; TUSHEMEREIRWE, W.; ADIPALA, E. Vector transmission of banana streak virus in the screen house in Uganda. Annals of Applied Biology, v. 139, n. 1, p. 37-43, 2001.

LOCKHART, B. E. L.; AUTREY, L. J. C.; COMSTOCL, J. C. Partial purification and serology of sugarcane mild mosaic virus, a mealybug transmitted closterolike virus. Phytopathology, v. 82, n. 6, p. 691-695, 1992. 
MESA, N. C.; GÓMEZ, E. D.; HUERTAS, C.; MENA, Y. M.; HERNANDEZ, C. A.; HENAO, E. D.; COBO, M. (ed.). Programa de manejo fitosanitario en piña en el departamento del Valle del Cauca. Palmira: Universidad Nacional de Colombia, 2014.

MILLER, D. R.; DAVIDSON, J. A. Armored scale insect pests of trees and shrubs. Ithaca: Cornell University Press, 2005.

NEIRA GARCÍA, A. M.; MARTÍNEZ REINA, A. M.; RODRÍGUEZ ORDUZ, J. O. Análisis del mercado de piña Gold y Perolera en dos principales centrales mayoristas de Colombia. Corpoica Ciencia y Tecnología Agropecuaria, v. 17, n. 2, p. 149-165, 2016.

R CORE TEAM. $R$ : a language and environment for statistical computing. Vienna: R Foundation for Statistical Computing, 2017.

RAINE, J.; MCMULlEN, R. D.; FORBES, A. R. Transmission of the agent causing little cherry disease by the apple mealybug Phenacoccus aceris and the dodder Cuscuta lupuliformis. Canadian Journal of Plant Pathology, v. 8, n. 1, p. 6-11, 1986.

RIOS, L. Colombia es un país rico en variedades locales de piña. Red Agrícola, n. 6, p. 36-38, 2020.

RODELO, M. Variabilidad genética del virus PMWaV-2 en piña (Ananas comosus) en Colombia. 2007. Undergraduate thesis (Agricultural Engineering) - Universidad Nacional de Colombia, Bogotá, 2007.

ROIVAINEN, O. Transmission of cocoa viruses by mealybugs (Homoptera: Pseudococcidae). Agricultural and Food Science, v. 48, n. 3, p. 203-304, 1976.

SADDIQ, B.; SHAD, A.: KHAN, H.A.;ASLAM, M.; EJAZ, M.; AFZAL, M. B. S. Resistance in mealybug Phenococcus solenopsis Tinsley (Homoptera: Psedococcidae) in Pakistan to selected organophosphates and pyrethroids insecticides. Crop Protection, v. 66, n. 1, p. 29-33, 2014.

SETHER, D. M.; HU, J. S. Yield impact and spread of pineapple mealybug wilt associated virus-2 and mealybug wilt of pineapple in Hawaii. Plant Disease, v. 86, n. 8, p. $867-874,2002$.
SETHER, D. M.; ULLMAN, D. E.; HU, J. S. Transmission of pineapple mealybug wilt-associated virus by two species of mealybug (Dysmicoccus spp.). Phytopathology, v. 88, n. 11, p. 1224-1230, 1998.

SIRISENA, U. G.; WATSON, G. W.; HEMACHANDRA, K. S.; WIJAYAGUNASEKARA, H. N. A modified technique for the preparation of specimens of Sternorrhyncha for taxonomic studies. Tropical Agricultural Research, v. 24, n. 2, p. 139-149, 2013.

THRESH, J. M. Crop viruses and virus diseases: a global perspective. In: COOPER, I.; KÜHNE, T.; POLISHCHUK, V. (ed.). Virus diseases and crop biosecurity. Dordrecht: Springer, 2006. p. 9-32.

TSAI, C. W.; ROWHANI, A.; GOLINO, D. A.; DAANE, K. M.; ALMEIDA, R. P. P. Mealybug transmission of grapevine leafroll viruses: an analysis of virus-vector specificity. Phytopathology, v. 100, n. 8, p. 830-834, 2010.

VENKATESAN, T.; JALALI, S. K.; RAMYA, S. L.; PRATHIBHA, M. Insecticide resistance and its management in mealybugs. In: MANI, M.; SHIVARAJU, C. (ed.). Mealybugs and their management in agricultural and horticultural crops. Bangalore: Springer, 2016. p. 223-229.

WACKERLY, D.; MENDENHALL, W.; SCHAFFER, R. Estadistica no paramétrica. In: WACKERLY, D.; MENDENHALL, W.; SCHAFFER, R. Estadistica matemática con aplicaciones. 7. ed. Ciudade de México, DF: Cengage Learning, 2010. p. 741-790.

WEBSTER, A. L. Prueba chi-cuadrado y otras muestras no paramétricas. In: WEBSTER, A. L. (ed.). Estadística aplicada a los negocios y la economía. Santa Fe de Bogotá: McGraw-Hill, 2000. p. 462-517.

WILLIAMS, D. J.; GRANARA DE WILLINK, M. C. Mealybugs of Central and South America. Wallingford: CAB International, 1992.

WILLIAMS, D. J.; WATSON, G. W. The scale insects of the tropical South Pacific region: Part 2: the Mealybugs (Pseudococcidae). Wallingford: CAB International, 1988. 